ISSN: 2299-8942

\title{
Extraction out of adjectival secondary predicates in English and Spanish: A nanosyntactic account
}

\author{
Antonio Fábregas and Ángel L. Jiménez-Fernández
}

\begin{abstract}
In this article, we explore the conditions under which prima facie adjectival adjuncts projected as depictive modifiers inside verbal phrases allow extraction. Building on the analysis of gerund clauses proposed in Fábregas and Jiménez-Fernández (in press), we argue that their empirical behaviour shows that, whenever these adjectival constituents license extraction, they are projections of PathP that form a verbal complex with the verb inside a single syntactic domain. This forces the conclusion that adjunct adjectives must be projected as PathPs, and in the last part of the paper we show that this proposal in fact explains two properties of these elements without further stipulations: they always receive a stage level interpretation, and cannot combine with pure stative verbs.
\end{abstract}

Keywords: secondary predicates, Aktionsart, adjuncts, extraction, nanosyntax

Introduction: the problem

Since Ross (1967) one of the main research topics in generative grammar has been to identify the principles that make movement (un)available from specific constituents. In the course of these debates, a generalisation that seemed to be extremely solid emerged: adjunct constituents act as closed islands for the purposes of extraction (Huang's, 1982, Condition on Extraction Domains; Stepanov, 2007; Chomsky, 2008; Jiménez-Fernández, 2009, 2012b; Haegeman, Jiménez-Fernández and Radford, 2014), as the following contrast shows:

$$
\begin{aligned}
& \text { a. What did John say [that Mary had read ? } \\
& \text { b. *What would John get very angry [if Mary had read }
\end{aligned}
$$

However, there is a variety of cases where it has been argued that extraction out of an adjunct has taken place. One of such cases is illustrated in (2). Example (2) involves what seems to be a non-selected adjectival constituent where the PP complement of the adjective has been extracted (see Demonte, 1987/1988, where these structures are noted for the first time; see also Borgonovo, 1994, 1996; Borgonovo and Neeleman, 2000; Truswell, 2007). These constructions are known in traditional Spanish grammar as predicados secundarios adjetivales, adjectival secondary predicates. Pace preposition stranding, Spanish and English behave in the same way with respect to these structures.

\footnotetext{
* The research underlying this article has been partly funded by the Research Project FFI2013-41509-P of the Spanish Government (MINECO) and, for the second author, by Grant 2014/15/B/HS2/00588 of the Polish National Science Centre (NCN).
} 
(2)
a. ¿Con quién llegó with whom arrived
[enfadada een quién] María?
angry
María
b. Whom did Mary arrive [angry with ?
$\begin{array}{llll}\text { c. ¿A qué volvió [adicto } & \text { Juan aqué]? } \\ & \text { to } & \text { what } & \text { came addicted }\end{array}$
d. What did John come back [addicted to what]?

(cf. Borgonovo and Neeleman, 2000, for English)

In Fábregas and Jiménez-Fernández (in press), we analysed other prima facie adjunct structures allowing extraction: gerund clauses such as What did he arrive whistling?. The main goal of this article is to show that the analysis proposed there for gerunds can be extended to depictive adjectival secondary predicates (henceforth DASPs). In fact, we will argue, extending the analysis in Fábregas and Jiménez-Fernández (in press) to these cases has the immediate consequence that we can explain several independent properties of DASPs in Spanish and English, for instance that they must be Stage-Level predicates.

In the course of the analysis, we will also see that the proposal entails that what descriptively has been called a single lexical verb has to correspond to a complex verbal unit in syntax, that is, a complex syntactic constituent with more than one XP.

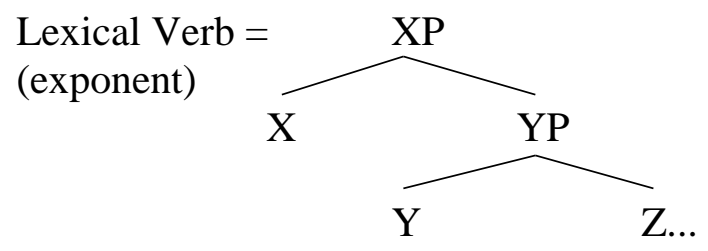

Within the syntactic space in (3), there is more than one head where lexical material can be introduced. The syntactic complexity of a single verb depends on its Aktionsart (Ramchand, 2008), because the heads that a verbal exponent lexicalises contain features defined by lexical or inner aspect. With this background, we analyse DASPs as forming a complex predicate by combining with the lexical verb in the syntax: within the space in (3), the verb lexicalises $X$ and Y, while the DASP lexicalises Z. From the perspective of syntax we have only one predicate and extraction is equally possible if the argument is introduced as part of XP or as part of ZP.

\section{$2 \quad$ Is there any syntax in Aktionsart?}

Before we introduce the empirical and technical details of this proposal, let us say a bit more about the theoretical background underlying our analysis. When it comes to how Aktionsart has been treated in the literature, two very different views have emerged: the lexical view accepts that Aktionsart may be complex at a lexical or lexico-semantic level, where 'complex' means that it is built by combining smaller primitives in a configuration; however, in syntax it behaves as atomic: all the features and their internal complexity are ignored, and the unit expressing aspect contributes a single head $\mathrm{X}^{0}$. This is particularly clear in approaches like Pustejovsky (1991), but also Jackendoff (1990) and Levin and Rappaport-Hovav (1995).

This view contrasts with the Neo-constructionist perspective, where Aktionsart is complex both at the semantic level and at the syntactic level, but never at the lexical level. The Narrow 
Lexicon contains only heads, each carrying a single feature which defines the specific aspect which they convey. To combine the primitives that define Aktionsart into a predicate, syntax is necessary; all the aspectual interpretation emerges from syntactic operations, particularly selection and head-complement structures (cf. Kempchinsky, 2000; Ramchand, 2008). ${ }^{1}$

In this work, we develop ideas put forth in Fábregas and Jiménez-Fernández (in press) by providing an argument in favour of a Neo-constructionist analysis of Aktionsart. Our argument follows this reasoning:

(a) The extraction from what seems to be an adjunct is possible under certain specific circumstances, involving a particular Aktionsart class of main predicates.

(b) Clearly, dealing with these objects as adjuncts violates restrictions which are independently established and motivated within Generative Grammar.

(c) One plausible way to resolve the tension consists in treating the 'adjunct' as part of the predicate. The DASP is not a genuine adjunct, but the spell-out of a syntactic constituent that together with the main verb forms a verbal complex in a relatively fine-grained decomposition of the verbal area. Thus, verbs must be built in the syntax, not in the lexicon.

If we adopt the lexical approach to Aktionsart, we are confronted with 2 problems that prevent any solution to the tension: (i) as the DASP cannot be treated as an adjunct, we are forced to stipulate operations of Reanalysis - Demonte (1987/1988, 1991), Zwart (1993), Stowell (1995) - to explain how the two predicates are fused into a single one in order to allow extraction and (ii) in doing so, we lose generalizations concerning aspect, locality and the extraction conditions under which something may be moved out of the fake 'adjunct'.

\section{Empirical restrictions to extraction out of DASPs}

Not any verb + DASP combination allows extraction in Spanish. In this section, we are going to review the conditions under which extraction out of DASP is possible. In the course of this discussion we will compare them to gerund clauses in order to show that their restrictions are strictly parallel and, therefore, that the analysis proposed for gerunds in Fábregas and Jiménez-Fernández (in press) can be plausibly extended to DASPs.

\subsection{Adjacency}

When a gerund clause in Spanish licenses extraction, the gerund has to be adjacent to the main verb, as (4) shows:

\footnotetext{
${ }^{1}$ Harley (1995), Hale and Keyser (2002), Mateu (2002) and other works can be considered as in between the two poles: they propose different flavours of the light verb $(v)$ so $v$ receives its aspectual reading in the Lexicon. However, for some authors there are distinct $v$ 's which combine together to get the interpretation (Rothmayr, 2009).
} 

Gerunds
what arrived
María whistling
b. ¿Qué llegó
what arrived
[silbando qué]
whistling
María?
'What did Mary arrive whistling?'

In the case of DASPs, adjacency is also an important component inside the conditions that license extraction. Example (5a), where the subject is between the adjective and the verb, is deemed ungrammatical, in contrast to $(5 b)$.
a. *Con quién volvió María [enfadada quién]?
with whom came María angry
b. ¿Con quién volvió [enfadada eon quién] María?
with whom came angry María?
'Whom did Mary return angry with?'

DASPs

In Fábregas and Jiménez-Fernández (in press), we argued that this property naturally follows if the prima facie adjunct is actually the spell-out of heads that form a head-complement sequence with the main verb, as in (6):

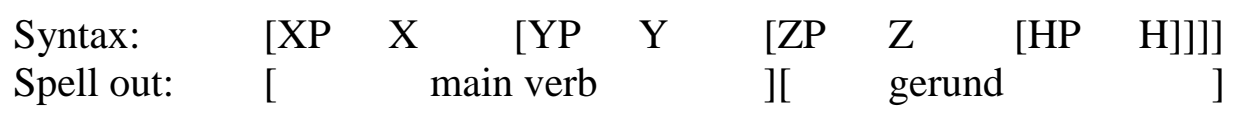

Under these conditions, we expect $\mathrm{XP}$ and $\mathrm{ZP}$ to move as a syntactic constituent when extraction is allowed; the subject is expected not to be able to appear between $\mathrm{Y}$ and $\mathrm{Z}$ on the standard assumption that its lowest position will be above XP. For the subject to intervene between the two constituents, ZP should be able to move in the absence of X-Y, followed by remnant movement of XP to an even higher position. Depending on the nature of $\mathrm{ZP}$, this movement should be blocked.

\subsection{The secondary predicate must refer to an internal argument}

Demonte (1987/1988), Borgonovo and Neeleman (2000) and Truswell (2007), among others, have noted that both gerunds and DASPs allow subextraction only to the extent that they modify the internal argument. Consequently, there is a contrast between unaccusatives and unergatives with respect to the possibility of extracting from a gerund clause:
a. $\quad$ *Wat did Mary dance whistling?
b. What did Mary arrive whistling?
a. $\quad$ *What did John dance dressed as? (Borgonovo and Neeleman, 2000, ex. (1b))
b. What did John arrive dressed as?


This restriction extends to DASPs:
a. $\quad *_{¿}$ Con quién bailó
with whom danced
[enfadada eon quién] María?
*'Who did Mary dance angry with?'
b. ¿Con quién llegó [enfadada eonquién] María?
with whom arrived angry María
'Who did Mary arrive angry with?'

If we look at transitive verbs, we find a similar restriction: when the DASP refers to the internal argument, extraction might be possible (if the other conditions are met), but when it refers to the subject, even if the other conditions are in place, the extraction is ungrammatical:

IA-oriented DASP

a. Perdi llena defotos la cartera que me regalaste.
I.lost full of photos the wallet, that $\mathrm{ME}$ you.gave
'I lost the wallet you gave me full of photos'

b. ¿De qué perdiste [llena qué]la cartera que te regalé? of what lost.you full the wallet that you I.gave

'What did you lose the wallet full of?'

(11) EA-oriented DASP

a. Perdí llena de pena la cartera que me regalaste. I.lost full of sorrow the wallet that ME you.gave 'Full of sorrow, I lost the wallet you gave me'

b. ¿ ¿De qué perdiste [llena dequé] la cartera que te regalé? of what lost.you full the wallet that you I.gave

'What did you lose the wallet full of?'

Example (10b) can be the equivalent of (10a), where the DASP full of photos refers to the wallet; in contrast, (11b) is an ungrammatical interrogative version of (11a), where full of sorrow refers to the person that lost the wallet.

\subsection{Aspectual constraints}

As with gerund clauses, it can be shown that extraction is only possible when the main verb is an achievement. All the previous grammatical examples have achievements as their verbs; in (12) it can be seen that when the verb is an accomplishment the extraction is ungrammatical even when the rest of the conditions are in place.
a. $\quad *_{\text {¿Qué }}$
what
adelgazó
slimmed
[comiendo qué] eating
(tres kilos)
'What did Juan reduced his weight in three kilos eating?'
b. Juan adelgazó
(tres kilos)
comiendo
arroz blanco.
Juan slimmed
three kilos
eating
rice white
'Juan lost three kilos of weight eating plain rice' three kilos Juan 
Activities also yield ungrammatical results:
a. $\quad *_{\text {¿Qué }}$
rodaba
[perdiendo qué]
el tonel?
what
rolled
losing
the
barrel
b. El tonel rodabapor
el monte perdiendo
aceite.
the barrel rolled by the mount losing
oil
'The barrel rolled down the mount losing oil.'

Finally, with stative verbs, the results (to the extent that gerund clauses can combine with statives, which is not general) are also ungrammatical.
a. * ¿Qué
descansaba leyendo
María?
what
rested
reading
María
'What was Mary resting reading?'
b. María descansaba leyendo el Quijote.
María rested reading the Quixote
'Mary was resting reading the Quixote.'

Exactly the very same restrictions apply to DASPs:
a. *Con quién contestó enfadada María? with whom answered angry María
'Who did Mary answer angry with?'
b. María contestó enfadada con su profesor.
María answered angry with her teacher

'Mary answered angry with her teacher.'
a. * ¿De quién buscó harta Juan a María?
of whom searched fed.up Juan ACC María
'Who did John look for Mary fed up with?'
b. *Juan buscó a María harta de tantas dietas.
Juan searched ACC María fed.up of so.many diets

'John looked for Mary fed up with so many diets.'
a. $\quad *_{\text {¿De quién esperaba harta María? }}$
of whom waited fed.up María
'Who was Mary waiting fed up with?'
b. María esperaba harta de su hermano.
María waited fed.up of her brother
'Mary was waiting fed up with his brother.'

Before going on with the analysis, let us say a bit more about the combination between DASPs and stative verbs: the non-dynamic verbs that allow them - esperar 'wait', descansar 'rest', dormir 'sleep' - can be argued to be so-called Davidsonian states (Maienborn, 2003), which are eventive even though they do not involve dynamicity. When we consider pure stative verbs (Kimian states in Maienborn, 2003), the generalisation noted in the literature (cf. Demonte and Masullo, 1999, for instance) is that these verbs normally do not allow secondary predicates. 


$\begin{array}{ll}\text { Juana odia las acelgas } & \text { (*harta). } \\ \text { Juana hates the chards } & \text { fed.up } \\ \text { 'Juana hates the chards fed up.' } & \end{array}$

The explanation of this restriction is unclear, but as we will argue in the next section, our analysis can derive it elegantly from the independent requisites imposed on DASPs.

What stative verbs allow are selected small-clause complements, such as those in (19):

$\begin{array}{lllll}\text { Juan encuentra a } & \text { María harta de la vida. } \\ \text { Juan finds } & \text { ACC María fed-up of } & \text { the } & \text { life } \\ \text { 'Juan finds / considers María fed up with life' } & & \end{array}$

These have never been treated as adjuncts, since their omission results in a semantically incomplete predicate. Being arguments, and specifically internal arguments of the verb, the fact that they allow extraction, like in (20), is unsurprising; we leave these argument small clauses out of the discussion, given that they are not properly DASPs and their analysis in traditional terms has always been unproblematic from the perspective of movement.

¿De qué encontró Juan [harta qué] a
of what found María?
'What did Juan find María fed up with?'

\section{$4 \quad$ A nanosyntactic analysis}

Our proposal's cornerstone is that extraction out of a DASP is possible only when the DASP lexicalises heads inside the $v \mathrm{P}$ phase, in such a way that verb and DASP belong to the same sequence of heads in the same syntactic domain. This implies that the subeventive heads lexicalised by the verb must (i) be in a sequence with those lexicalised by the DASP and (ii) be distinct, so that the presence of one does not compete with the presence of the other.

Ramchand (2008, pp. 38 and ff.) argues that the $v \mathrm{P}$ phase is internally composed of at least three heads, corresponding to the three traditionally identified basic subevents (Dowty, 1979; Pustejovsky, 1991; Jiménez-Fernández and Tubino, 2014, inter alia):

a) Initiation: the head which encodes the ingredient of Cause when it is part of an event.

b) Process: the head which provides the verb with its eventive part.

c) Result: the head which conveys the state that follows a telic event when the latter arrives at its ending-point.

The head Process defines an event, but it does not determine the properties of such an event on its own. For instance, it does not give information on whether the event will describe a change or not (Fábregas and Marín, 2012, in press). Only if a change across a dimension is denoted, will an additional head be added, namely PathP - an ordered sequence of points that can be used to measure an event by one-to-one isomorphism (Ramchand, 2008, p. 51). Consider, as an illustration, (21). 
(21) a. John ran into the forest.

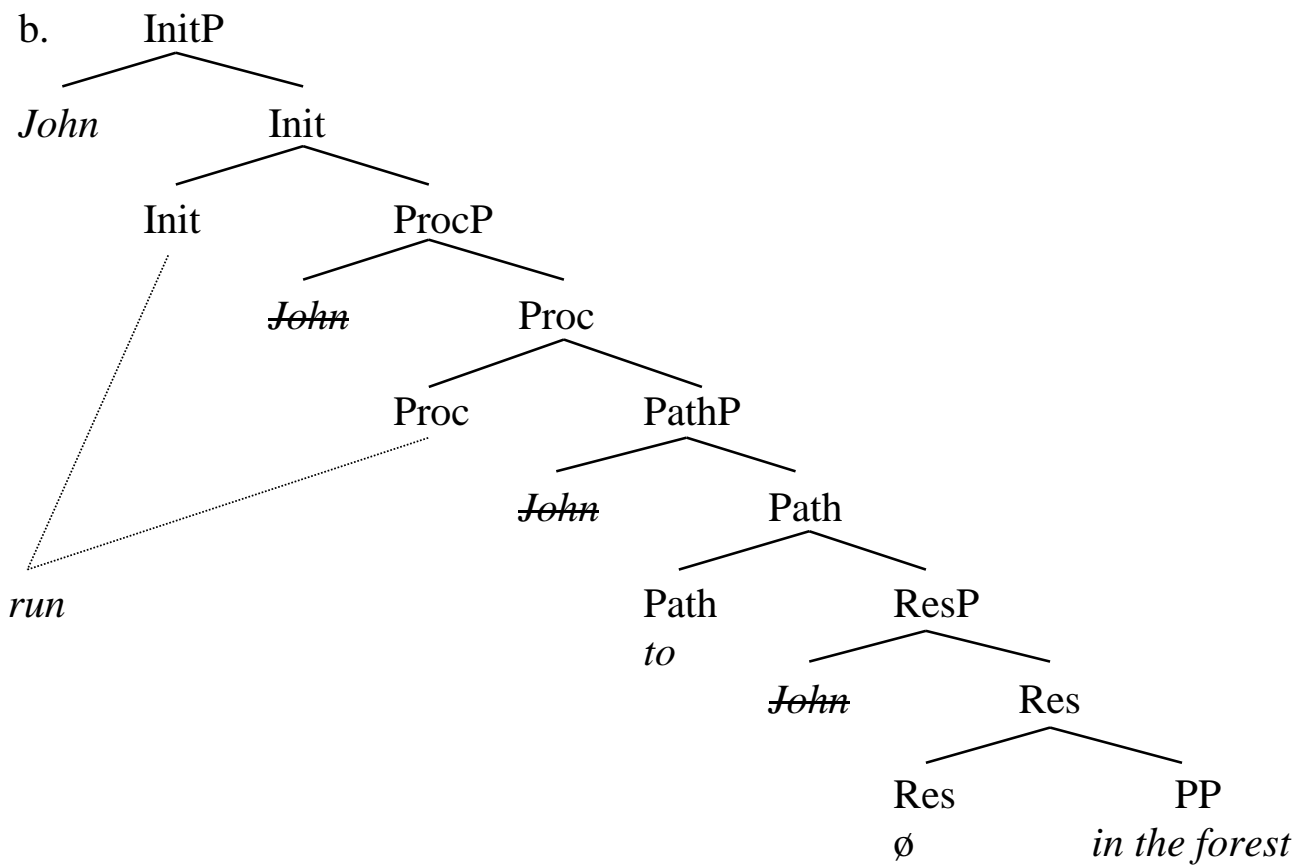

This reads as follows: there is a dynamic event (Proc) involving John; that event has a causative part, controlled by John (Init), and is defined as an incremental change across a spatial path defined as a set of points in a trajectory (Path, to). That incremental change culminates in a result state (Res) which is the situation where John is in the forest.

With this background in mind, remember the properties that allow extraction out of DASPs:

(i) the DASP and the verb are adjacent

(ii) the DASP must take the verb's internal argument as its subject

(iii) the verb must be an achievement.

Let us start from the last one: the crucial property of achievements is that their denotation does not involve a PathP, precisely because they denote transitions which do not occupy an extended period of time (cf. Piñón, 1997, where they are defined as boundaries of change without associated processes). In a Ramchandian perspective, this means that achievements define events (thus, ProcP), but do not involve a PathP: as the event does not take as its complement an ordered series of points, the event cannot be defined as an incremental change across a dimension, and thus lacks extension. Example (22) illustrates this case. 
a. John jumped in the lake.

b
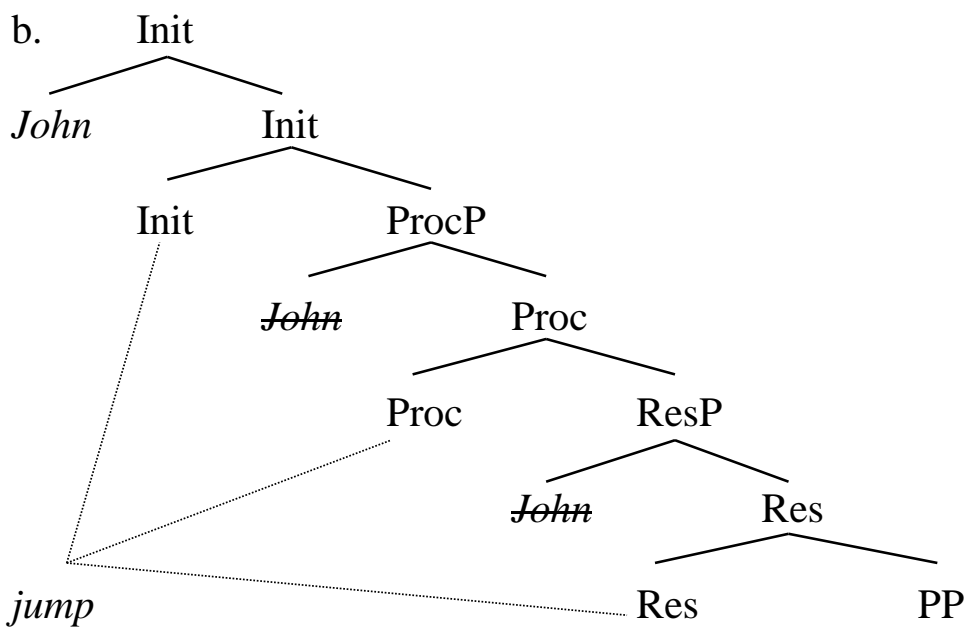

in the lake

What is the consequence of this distinction for extraction out of prima facie adjuncts? In Fábregas and Jiménez-Fernández (in press) it was extensively argued that the extraction is only possible when both gerund and main verb share the four syntactic heads in the first phase: Init, Proc, Path and Res. Specifically, we argued, the main verb identified Init, Proc, and possibly Res, while the gerund was a projection of PathP. Gerunds were analysed, essentially, as infinitival forms headed by a Path preposition (cf. also Gallego, 2010).

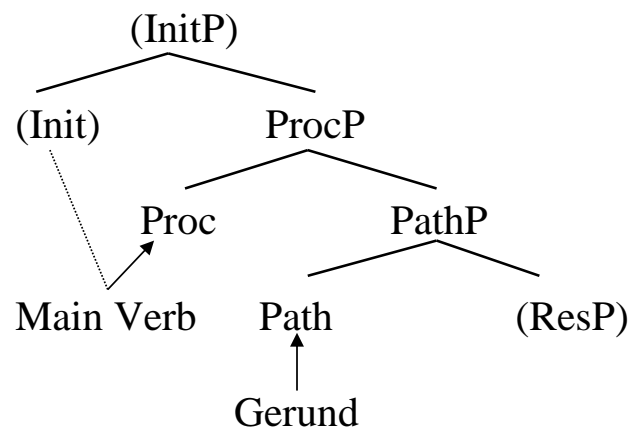

Given this situation, what we expected was that achievements should be the only Aktionsart class that allowed extraction from gerund clauses, precisely because it is the only Aktionsart class which contains Proc in its structure but does not occupy Path with an element that gives the event temporal extension. Stative verbs lack ProcP, because they are not eventive; without ProcP, no PathP can be projected, as the ungrammaticality of (24) shows, where we plug a path preposition to a stative verb.

$$
\text { *John is to the bridge. }
$$

As for activities and accomplishments, their events have temporal extension, so PathP has to be associated with their ProcP, or, in other words, has to be isomorphically identified with their ProcP. This makes the PathP unavailable for the gerund. 
(25)

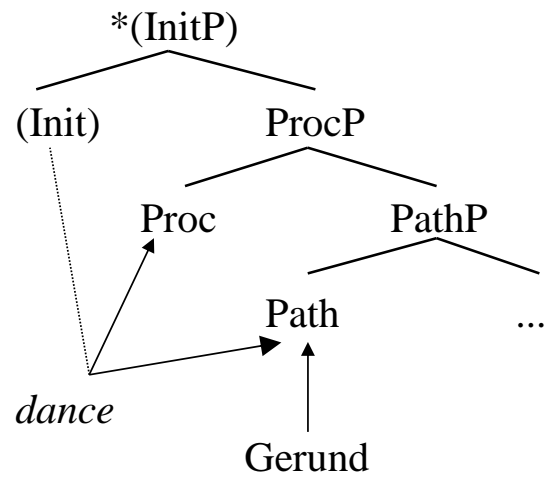

The claim that the gerund clauses allowing extraction project as PathPs in the spine of the tree has two immediate consequences: the first one is that the verb and the gerund are expected to be adjacent, because they are the spell-out of adjacent heads in a head-complement relation. Extraction will only be allowed when the configuration still is head-complement. The second consequence is that, by pure Relativised Minimality, we expect the projection of the gerund as a PathP to allow it just to take an internal argument as subject. Let us see why.

Within the Nanosyntactic system, being an internal argument means that the relevant constituent must occupy the specifier of ProcP (independently of whether the very same element is ultimately moved to spec-InitP too). On the other hand, being an external argument means that it is base-generated in InitP, and it has not been merged in spec-ProcP before.

Given this structural configuration, the reason why gerunds must take the internal argument as subject follows from an intervention effect. As PathP is lower than ProcP, the specifier of PathP can become the specifier of ProcP by movement. From there it can further move to spec-InitP or not.

(26)

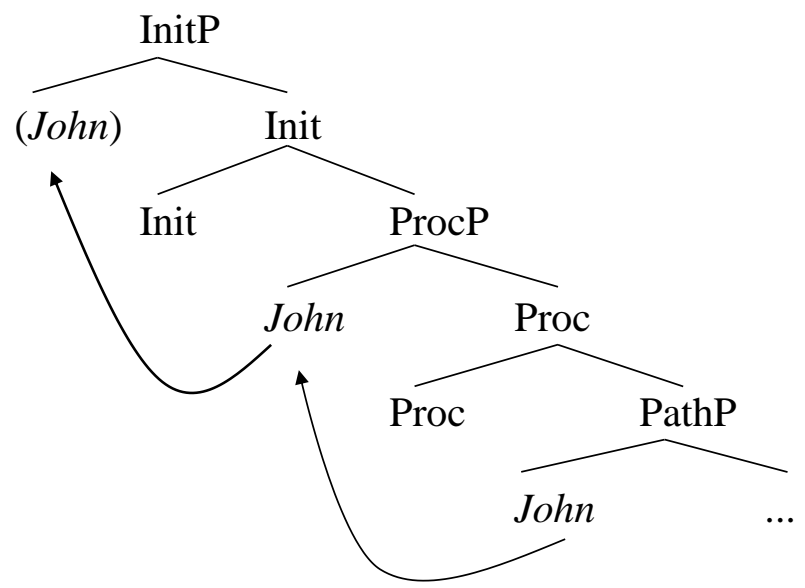

What is impossible, however, is that spec-PathP moves directly to spec-InitP without landing first in spec-ProcP. If ProcP and PathP have different specifiers, then the one in spec-ProcP will land in InitP, since that movement is more local. 
(27)

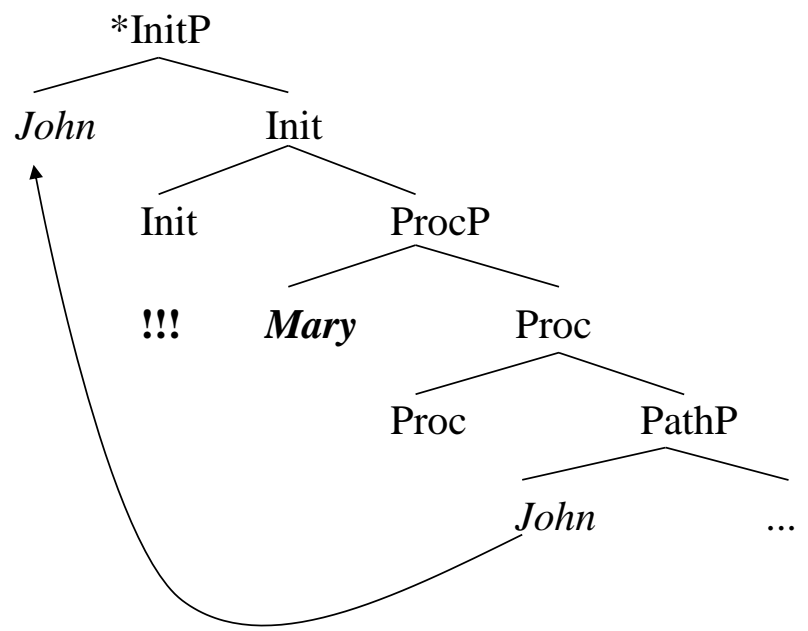

\section{Intervention}

Consequently, if the extraction happens, the gerund must be integrated in the same syntactic structure as the main verb, as a PathP. ProcP will always be closer to Init than PathP. Thus, if the specifiers of Path and Proc are different, the one belonging to Proc will always move to spec-InitP, with the result that the argument introduced by PathP will not end up in InitP: the gerund that allows subextraction will never be predicated of an external argument.

\subsection{DASPs as projections of PathP}

Given that the properties of extraction out of gerunds are identical to those restricting the extraction out of DASPs, the unavoidable conclusion is that DASP, when they allow extraction, must be also a projection of PathP inside the spine of the tree. Specifically, we propose the structure in (28) for extraction-allowing DASPs; while our contention is that all secondary adjectival predicates will be headed by Path, we restrict the claim that they are merged as complements to Proc to just the cases where the extraction is allowed; we remain neutral with respect to whether they also integrate in the verbal complex in cases where there is no extraction, as under those conditions they could also be merged as adjuncts. This possibility explains the integration in the case of achievements and their plausible nonintegration in the case of other aspectual classes.

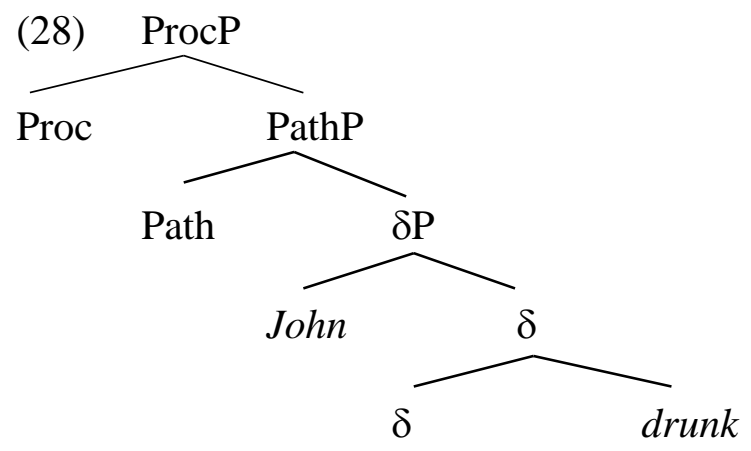

Let us go step by step. DASPs allowing extraction are adjectives, and in contrast with gerunds (which contain verbal structure inside them), it has been extensively argued that adjectives do not introduce their subjects lexically inside the AP projection (Hale and Keyser, 2002; Baker, 2003). The role of the head $\delta$ in the structure is, in line with Hale and Keyser (2002, p. 219), a stative predicative head which turns the adjective into a predicate, so that it licenses a specifier which acts as subject of the predication (see also Bowers', 2000, proposal of PredP, that is however extended in principle also to verbs, something that Baker, 2003, argues 
against; cf. also Brucart, 2010; Jiménez-Fernández, 2012a). This projection, then, introduces the subject that ultimately will raise to PathP and become the subject of the whole subevent integrated in the spine of the tree.

The difference between a normal adjectival construal and a DASP projected as part of a verbal complex is that PathP is a compulsory projection in the second case, but not in the first. When the adjective is used as a DASP, since $\delta$ is not one of the heads belonging to the verbal domain, its presence is not enough the make the constituent integrate inside the same verbal space as the verb. That is why PathP must dominate the whole structure, and as a projection of Path, the whole constituent can integrate in the verbal sequence in the same way as gerunds do.

In the following sections we will argue that this is not only technically possible, but in fact can explain different independent properties of DASPs.

\subsection{DASPs must be stage level predicates}

Our claim that DASPs must project as PathPs is supported by a solid empirical generalisation: DASPs must always be interpreted as Stage-Level Predicates (Carlson, 1977; Kratzer, 1995):

$$
\begin{aligned}
& \text { a. Juan volvió de la fiesta \{enfermo / *inteligente }\} \\
& \text { Juan returned from the party sick / intelligent } \\
& \text { 'John returned from the party sick/*intelligent.' } \\
& \text { b. Juan se bebió el café \{frío / *descafeinado }\} \\
& \text { Juan SE drank the coffee cold / decaffeinated } \\
& \text { 'John drank his coffee cold/*decaffeinated.' } \\
& \text { c. Juan llegó } \quad \text { harto / CCristiano }\} \\
& \text { Juan arrived fed.up / Christian } \\
& \text { 'John arrived fed up/*Christian.' }
\end{aligned}
$$

Adjectives can, of course, also be individual level predicates:

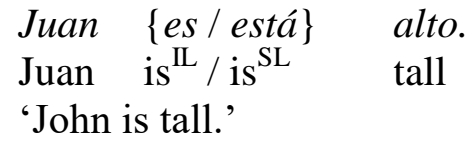

However, when projected as DASPs, they must be interpreted as Stage Level:

Mi hijo volvió $\quad \begin{aligned} & \text { alto del } \\ & \text { my son returned tall from.the }\end{aligned}$ campamento.
'My son returned tall from the camp.'

Sentence (31) must mean that my son, after the time he spent in the camp, became taller; it cannot mean that my son, who is characteristically tall, returned from the camp. Thus, whenever an adjective is projected as a DASP, it must be interpreted as an SL predicate.

This follows automatically from our claim that DASPs integrate in the spine of the tree by the intermediation of PathP. PathP defines, as we have said, a sequence of points which can have a final culmination point. In fact, Hale (1986) defined the path reading of prepositions as Terminal Coincidence Relations, which, in his proposal, were underspecified with respect to whether they applied to temporal, spatial or even modal domains. Terminal Coincidence 
relations define contact with another entity, while Central Coincidence relations are generally associated with inclusion, and thus with static locations as opposed to paths.

This Terminal Coincidence relation has been explicitly used as an aspectual constituent in Mateu (2002), among other authors: it is associated for instance with perfective readings of predicates, ${ }^{2}$ in opposition to the imperfective readings of the same predicates, which are defined by Central Coincidence relations.

Even more directly relevant to our own purposes, the Terminal Coincidence relation has been used in previous work to define stage level adjectival predicates in opposition to individual level adjectival predicates. As far as we know, the first to propose this was Brucart (2010), who codified the stage level copula in Spanish, estar, as a verb that combines with Terminal Coincidence-marked predication phrases because of its need to value case (see also Camacho, 2012):

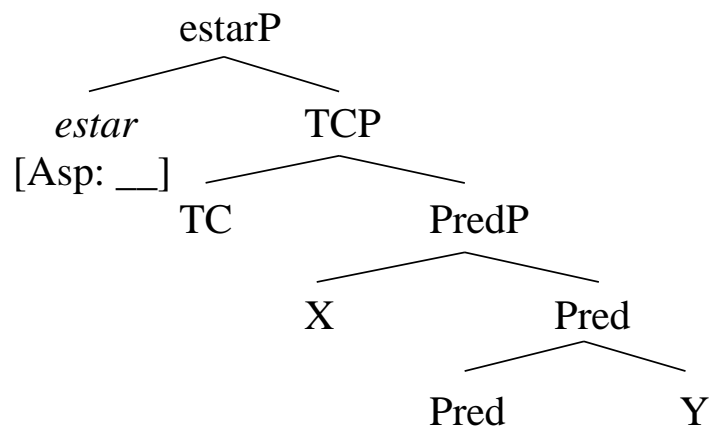

Pace the labels used, our structure is equivalent to this: PathP corresponds in this system to Terminal Coincidence (TC) relations, given that it defines trajectories as opposed to static locations, and $\delta$ stands for the predication phrase. If stage level predicates are those that are headed by Path, then our proposal that DASPs must integrate with the spine of the verb as PathPs derives why DASPs are restricted to stage level interpretations: an individual level reading is excluded because it is not dominated by PathP, and therefore cannot become a verbal complex with the main verb.

\subsection{Stative verbs do not admit DASPs}

The second immediate consequence of suggesting that DASPs are PathPs is that we derive, rather than stipulate, why pure stative verbs cannot accept DASPs. If DASPs are PathPs, their ungrammaticality with pure stative verbs follows from the proposal that stative verbs lack ProcP, and the role of PathP is precisely to define properties of the event variable contained in ProcP.

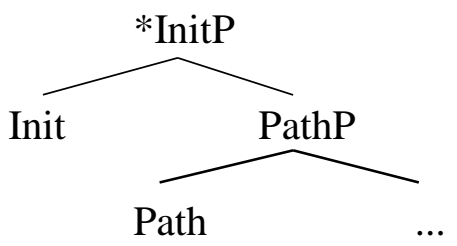

The impossibility of having, then, a sentence like (34) follows from the same categorymismatch that makes *John is to the bridge ungrammatical.

\footnotetext{
${ }^{2}$ See Arche (2012) for a wide-ranging analysis of external aspect in relational terms.
} 


$\begin{array}{lll}\text { *Pedro } & \text { sabe inglés } & \text { contento } \\ \text { Pedro } & \text { knows English } & \text { happy } \\ \text { 'Peter knows English happy.' } & \end{array}$

\section{Conclusions}

In this short contribution, we have shown that the conditions under which prima facie adjectival adjuncts admit extraction are identical to those exhibited by gerund clauses. Building on the gerund clause analysis in Fábregas and Jiménez-Fernández (in press), we have reached the conclusion that this set of properties, as in the case of gerunds, implies that DASPs are syntactically defined as PathPs which become part of the verbal complex whenever extraction is possible. We have furthermore argued that the conclusion that DASPs are PathPs is independently desirable, given that this allows us to explain two properties that, to the best of our knowledge, had to be stipulated or simply described in other proposals. First, DASPs must be stage level predicates, something that in our proposal follows naturally from their being headed by a PathP whenever they have to integrate with the verb. Second, if DASPs are PathPs, the fact that they cannot combine with pure stative verbs is explained by the lack of ProcP in the internal structure of these predicates.

Once DASPs have been shown to allow extraction only under the precise conditions expected if they are integrated as projections of PathP, the extraction facts do not constitute an argument against the generalisation that adjuncts behave like islands, essentially because DASPs are, in that configuration, the spell-out of heads inside the head-complement sequence defined as the verbal domain. This also makes reanalysis or other procedures unnecessary to accommodate these facts in our current theoretical universe, where adjuncts are in principle closed domains.

\section{References}

Arche, M. J. (2012). On the aspectuality of the individual-level/stage-level dichotomy. Borealis, $1,109-132$.

Baker, M. C. (2003). Lexical categories: verbs, nouns and adjectives. Cambridge: Cambridge University Press.

Borgonovo, C. (1994). The parametric syntax of gerunds. (Doctoral dissertation). Brandeis University, Waltham, MA.

Borgonovo, C. (1996). Gerunds and perception verbs. Languages et Linguistique, 22, 1-19.

Borgonovo, C. and Neeleman, A. (2000). Transparent adjuncts. Canadian Journal of Linguistics, $45,199-224$.

Bowers, J. (2000). Predication. In M. Baltin and C. Collins (Eds.), The handbook of contemporary syntactic theory (pp. 299-333). Oxford: Blackwell.

Brucart, J. M. (2010). La alternancia ser/estar y las construcciones atributivas de localización. In A. Avellana (Ed.), Actas del V Encuentro de Gramática Generativa (pp. 115-152). Neuquén: EDUCO.

Camacho, J. (2012). Ser and estar: The individual/stage-level distinction and aspectual predication. In J. I. Hualde, A. Olarrea, and E. O'Rourke (Eds.), The handbook of Hispanic linguistics (pp. 453-477). Malden, MA: Wiley-Blackwell. 
Carlson, G. N. (1977). Reference to kinds in English. (Doctoral dissertation). University of Massachusetts, Amherst.

Chomsky, N. (2008). On phases. In R. Freidin, C. P. Otero, and M. L. Zubizarreta (Eds.), Foundational issues in linguistic theory. Essays in honor of Jean-Roger Vergnaud (pp. 133166). Cambridge, MA: MIT Press.

Demonte, V. (1987/1988). Remarks on secondary predicates: C-command, extraction and reanalysis. The Linguistic Review, 6, 1-39.

Demonte, V. 1991. Temporal and aspectual constraints on predicative APs. In H. Campos and F. Martínez-Gil (Eds.), Current studies in contemporary Romance linguistics (pp. 413-450). Amsterdam: John Benjamins.

Demonte, V. and Masullo, P. J. (1999). La predicación: Los complementos predicativos. In I. Bosque and V. Demonte (Eds.), Gramática descriptiva de la lengua española (pp. 24612525). Madrid: Espasa.

Dowty, D. R. (1979). Word meaning and Montague grammar. Dordrecht: Reidel.

Fábregas, A. and Jiménez-Fernández, Á. L. (in press). Extraction from gerunds and the internal syntax of verbs. Linguistics.

Fábregas, A. and Marín, R. (2012). State nouns are Kimian states. In I. Franco, S. Lusini, and A. Saab (Eds.), Romance languages and linguistic theory 2010 (pp. 41-65). Amsterdam: John Benjamins.

Fábregas, A. and Marín, R. (in press). Severing dynamicity from eventivity. Linguistics.

Gallego, Á. (2010). On the prepositional nature of non-finite verbs. Catalan Journal of Linguistics, 9, 79-102.

Haegeman, L., Jiménez-Fernández, Á. L., and Radford, A. (2014). Deconstructing the Subject Condition in terms of cumulative constraint violation. The Linguistic Review, 31(1), 73-150.

Hale, K. (1986). Notes on world view and semantic categories. Some Warlpiri examples. In P. Muysken and H. van Riemsdijk (Eds.), Features and projections (pp. 233-254). Dordrecht: Foris.

Hale, K and Keyser, S. J. (2002). Prolegomenon to a theory of argument structure. Cambridge, MA: MIT Press.

Halle, M. and Marantz, A. (1993). Distributed morphology and the pieces of inflection. In K. Hale and S. J. Keyser (Eds.), The view from Building 20 (pp. 111-176). Cambridge, MA: MIT Press.

Harley, H. (1995). Subjects, events and licensing. (Doctoral dissertation). MIT, Cambridge, MA.

Huang, J. (1982). Logical relations in Chinese and the theory of grammar. (Doctoral dissertation). MIT, Cambridge, MA.

Jackendoff, R. (1983). Semantics and cognition. Cambridge, MA: MIT Press.

Jackendoff, R. (1990). Semantic structures. Cambridge, MA: MIT Press.

Jiménez-Fernández, Á. L. (2009). On the composite nature of subject islands: A phase-based approach. SKY Journal of Linguistics, 22, 91-138.

Jiménez-Fernández, Á. L. (2012a). What information structure tells us about individual/stage predicates. Borealis: An International Journal of Hispanic Linguistics, 1 (1), 1-32.

Jiménez-Fernández, Á. L. (2012b). A new look at subject islands: The phasehood of definiteness. Anglica Wratislaviensia, 50, 137-168. 
Jiménez-Fernández, Á. L. and Tubino, M. (2014). Variación sintáctica en la causativización léxica. Revista Española de Lingüística, 44(1), 7-37.

Kempchinsky, P. (2000). Aspect projections and predicate type. In H. Campos, E. Herburger, A. Morales-Front, and T. J. Walsh. (Eds.), Hispanic linguistics at the turn of the millenium (pp. 171-187). Somerville: Cascadilla Press.

Kratzer, A. (1995). Stage-level and individual-level predicates. In G. Carlson and F. J. Pelletier (Eds.), The generic book (pp. 125-175). Chicago: University of Chicago Press.

Levin, B. and Rappaport-Hovav M. (1995). Unaccusativity: At the syntax-lexical semantics interface. Cambridge, MA: MIT Press.

Maienborn, C. (2003). Die logische Form von Kopula-Sätzen. Berlin: Akademie Vorlag.

Mateu, J. (2002). Argument structure: Relational construal at the syntax-semantics interface. (Doctoral dissertation). Universitat Autònoma de Barcelona, Barcelona.

Pesetsky, D. (1995). Zero syntax. Cambridge, MA: MIT Press.

Piñón, C. (1997). Achievements in event semantics. In A. Lawson and E. Cho (Eds.), Proceedings of SALT VII (pp. 276-293). Ithaca (NY): CLC Publications.

Pustejovsky, J. (1991). The syntax of event structure. Cognition, 41, 47-81.

Ramchand, G. (2008). Verb meaning and the lexicon. Cambridge: Cambridge University Press.

Ross, J. R. (1967). Constraints on variables in syntax. (Doctoral dissertation), MIT, Cambridge, MA.

Rothmayr, A. (2009). The structure of stative verbs. Amsterdam: John Benjamins.

Stepanov, A. (2007). The end of CED? Minimalism and extraction domains. Syntax, 10(1), 80126.

Stowell, T. (1995). Remarks on clause structure. In A. Cardinaletti and M. T. Guasti (Eds.), Syntax and semantics 28: Small clauses (pp. 271-286). San Diego: Academic Press.

Truswell, R. (2007). Extraction from adjuncts and the structure of events. Lingua, 117, 13551377.

Vendler, Z. (1967). Facts and events. In Z. Vendler (Ed.), Linguistics in philosophy (pp. 122-146). Itaca, NY: Cornell University Press.

Verkuyl, H. J. (1993). A theory of aspectuality. The interaction between temporal and atemporal structure. Cambridge: Cambridge University Press.

Zwart, J.-W. (1993). Dutch syntax: A minimalist approach. (Doctoral dissertation). Rijksuniversiteit Groningen.

Antonio Fábregas

Universitet i Troms $\varnothing$

Institute of Language and Culture

HSL Fakultet

N-9037, Tromsø, Norway

e-mail: antonio.fabregas@uit.no
Ángel L. Jiménez-Fernández

University of Seville

Departamento de Filología Inglesa (Lengua Inglesa)

C/ Palos de la Frontera s/n

41004 Sevilla, Spain

e-mail: ajimfer@us.es 